\title{
Physicochemical Properties of Manzala Lake, Egypt
}

Randa R. EImorsi ${ }^{*}$, Mohamed A. Hamed ${ }^{1}$ and Khaled S. Abou-El-Sherbini'

${ }^{1}$ National Institute of Oceanography and Fisheries, Suez Branch, Adabiyah-Suez

Road, Attaqa District, Suez and '2Department of Inorganic Chemistry, National Research Centre, 33 El Bohouth st. (former Eltahrir st.), Dokki, Giza 12622, Egypt

\begin{abstract}
$\mathbf{P}$ HYSICOCHEMICAL parameters such as temperature, total dissolved solid (TDS), $\mathrm{pH}$, salinity, dissolved oxygen (DO), biological oxygen demand (BOD), permanganate index (PI), chloride and nutrient salts were measured in water samples, collected from 12 sites of Manzala Lake during winter and summer, 2015. A lot of fluctuations were observed in these parameters affected by the poor connection of water body of the lake and the diversity of the incoming flows. The $\mathrm{pH}$ values of water were alkaline throughout the lake and closely correlated with widely varied salinity and DO values. BOD increases in the south easternlocated sites affected mostly by Bahr El Baqur drain effluents especially during winter during the scheduled water block. PI was highly influenced by the agricultural and domestic waste effluents. Nutrients salts ranged between 5.47-249, 2.61-15.1, 0.64-24.5, and 3.47-22.9 $\mu \mathrm{mol}$ $\mathrm{L}^{-1}$ for ammonia, nitrite, nitrate and phosphate, respectively. N/P ratios $(2.28-12.8)$ in the present study indicated that nitrogen is the limiting factor for phytoplankton fluorination except for some sites in the south eastern region. The levels of total polycyclic aromatic hydrocarbons were found affected by the seawater inflows during winter. It can be concluded from obtained data that the south eastern region showed worst water quality parameters.
\end{abstract}

Keywords: Brackish water, Nutrients, Physicochemical parameters, Total polyaromatic hydrocarbons.

\section{Introduction}

Manzala Lake (Fig. 1) is the largest coastal lake in Egypt which is a shallow brackish lake extending between the Damietta Nile River branch and the Suez Canal with a maximum length of $50 \mathrm{~km}$ along the Mediterranean coast [1]. The northern boundary of the lake is connected with some narrow inlets such as El-Gamil canal with the sea. The eastern boundary is Suez Canal that is connected with the lake via El-Qabuty canal. Economically, Manzala Lake is considered as one of the most valuable fish sources in Egypt by about $36-50 \%$ from the total annual production of the Egyptian lakes. This contributes $>4.2 \%$ of the total country fish production; ca. 1.5 million ton $[2,3]$.

During the last few decades, the lake has undergone obvious environmental changes due to human activities that have a serious impact on the lake. The lake changed from a connected regenerated saline water body to semi-closed sub-basins as far as the narrow water exchange inlets are not sufficient. Also, the lake receives large amounts of untreated sewage and irrigation returns; ca. 3 milliard m3 annually [4]. Domestic, agricultural and industrial effluents are brought from urban centers along the lengths of main drains such as Bahr El Baqur through which more than $30 \%$ of the inflow passes to the lake [5]. Hydrological conditions of lake water affects the aquaculture activities resulting in a decrease in fish productivity, change in species composition avifauna, eutrophication and an overall loss of biodiversity $[3,6]$.

Water quality monitoring is the integrated activity for assessing the physical, chemical and biological features of water in relation to human

* Corresponding author e-mail: rrelmorsi@hotmail.com

DOI :10.21608/ejchem.2017.776.1025

C2017 National Information and Documentation Center (NIDOC) 
health, ecological conditions and designated water uses [7]. The most widely measured quality parameters are $\mathrm{pH}$, dissolved oxygen (DO), electrical conductivity (EC), total dissolved solids (TDS), turbidity, and chlorophyll.

In addition, the discharge of nitrogen to the lake water is of concern for a number of reasons. Excessive accumulation of nitrogen in surface waters can lead to ecological inequities that may cause overgrowth of plants and animals, leading to water quality degradation (eutrophication). Ammonia nitrogen may deplete DO in natural waters by microbial nitrification reactions. Also, high ratio of the unionized ammonia species develops at high $\mathrm{pH}$ that is toxic to fish and other aquatic life [7]. Nitrate and nitrite constitute a public health concern, primarily related to methemoglobinemia and carcinogenesis [8].

Recent reports encountered that Manzala Lake is contaminated with levels of organochlorines, although not higher than the maximum permissible level [9-11]. On the other hand, the highest contents of total polycyclic aromatic hydrocarbons (TPAHs) in the surface sediments along the Egyptian Mediterranean coast were found in the seashore near Manzala Lake; 4895$6338 \mathrm{ng} \mathrm{g}-1$ [12].

Fortunately, pollutants usually concentrate in the liver, kidney or gill tissue of fish species and not to the same extent in the body muscles that make it safe food if these organs are discarded $[13,14]$. However, continuous assessment of water quality parameters is necessary to monitor and understand the effect of different water resources on water quality of Manzala Lake. The aim of the present study is to assess the physicochemical properties of water in Manzala Lake during winter and summer 2015.

\section{Materials and Methods}

\section{Study area}

Manzala Lake is located on the northeastern edge of the Nile Delta within three governorates; Dakahlia, Damietta and Port Said, and separated from the Mediterranean Sea by a sandy beach bridge [15]. It is located between latitudes $31^{\circ} 07^{\prime} \mathrm{N}$ and $31^{\circ} 30^{\prime} \mathrm{N}$ and longitudes $31^{\circ} 48^{\circ} \mathrm{E}$ and $32^{\circ} 17^{`} \mathrm{E}$ (Fig. 1). Over 1,000 islands of different sizes are scattered throughout the lake, some of them are inhabited. Large areas in the north-west of the lake have been changed into fish farms, while much of the southern part of the lake is being prepared for its conversion to agricultural use. Wastewater effluents are flowing into Manzala Lake from nine major drains and canals. Faraskur, Al Sarw, Baghous, Abu Garida and Bahr El Baqur are the most important of them. The last drain is the most polluted which carries mostly untreated wastewater originating from Cairo and contributing much to the deteriorating water quality of the lake. The samples were collected two times during a 1 -year period (10/2/2015 and 15/9/2015) as described below.

\section{Samples collection}

Surface water samples were collected from 12 sampling sites along Manzala Lake using Nansen bottles at a $50 \mathrm{~cm}$ depth during the period of study. Sampling sites were covering different criteria of the lake as detailed in Table 1 and Fig.1. The water samples were filtrated through a Whatmann filter paper in order to remove debris and particulates. The filtrated water samples were then kept at -15 ${ }^{\circ} \mathrm{C}$ until further analysis.

\section{Procedures}

Results were averages of 5 replicates with RSD below 2\%. Samples have been subjected to various analyses at the time of sampling including water temperature $(\mathrm{T})$ using a digital thermometer, depth by standard meter, $\mathrm{pH}$ value and $\mathrm{EC}$ by using portable devices ( $\mathrm{pH}$ meter model HI 8314 and digital conductivity meter HI2300 Hanna Ins. Romania).

TDS, DO, biochemical oxygen demand (BOD5), permanganate index (PI), chloride content $(\mathrm{Cl})$, alkalinity, ammonia, nitrite, nitrate, dissolved reactive phosphate and total polyaromatic hydrocarbons (TPAHs) were analyzed in the laboratory by following standard methods [16].

The $\mathrm{pH}$ value was confirmed in laboratory by Consort C860 (Parklaan), 36 B-2300 Turnhout. TPAHs were measured by digital spectrofluorometer model 450 from Sequioaturner Corporation. Nutrient salts; $\mathrm{NH}_{3}, \mathrm{NO}_{2}^{-}$, $\mathrm{NO}_{3}{ }^{-}$and $\mathrm{PO}_{4}{ }^{3-}$ were determined by using Beckman Du-6-UV-Visible single beam spectrophotometer.

\section{Statistical analysis}

Pearson correlation bivariate two-tailed test were used to evaluate the significant difference in water quality parameters of different study sites. A probability at level of 0.05 or less was considered significant [17]. 
TABLE 1. Sites of water samples collected from Manzala Lake and their influencing effluents

\begin{tabular}{|c|c|c|c|c|c|c|c|c|c|}
\hline \multirow[t]{2}{*}{ Site } & \multicolumn{3}{|c|}{ Latitude } & \multicolumn{3}{|c|}{ Longitude } & \multirow[t]{2}{*}{ Nearest effluent } & \multirow[t]{2}{*}{ Type of effluent } & \multirow[t]{2}{*}{ Mean inflow, $\mathrm{m}^{3} / \mathrm{s}$} \\
\hline & $\circ$ & & 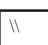 & $\circ$ & & $\Pi$ & & & \\
\hline 1 (El-Matteriah) & 31 & 09 & 23 & 32 & 05 & 17 & $\begin{array}{l}\text { Ramsis } \\
\text { Hadus }\end{array}$ & $\begin{array}{l}\text { agricultural waste } \\
\text { agricultural waste }\end{array}$ & $\begin{array}{l}19 .[4] \\
5.44[15]\end{array}$ \\
\hline 2 (Genka) & 31 & 06 & 06 & 32 & 06 & 41 & $\begin{array}{l}\text { Ramsis } \\
\text { Hadus }\end{array}$ & $\begin{array}{l}\text { agricultural waste } \\
\text { agricultural waste }\end{array}$ & $\begin{array}{l}19.1[4] \\
5.44[15]\end{array}$ \\
\hline 3 (Ras Set Elbanat) & 31 & 10 & 55 & 32 & 05 & 56 & $\begin{array}{l}\text { Ramsis } \\
\text { Hadus }\end{array}$ & $\begin{array}{l}\text { agricultural waste } \\
\text { agricultural waste }\end{array}$ & $\begin{array}{l}19.1[4] \\
5.44[15]\end{array}$ \\
\hline 4 (Elbashtir) & 31 & 1 & 40 & 32 & 09 & 24 & new Bahr Elbaqur & mixed wastes & $50.4[15]$ \\
\hline 5 (El-Gamil) & 31 & 14 & 31 & 32 & 11 & 50 & $\begin{array}{l}\text { El- Qabuty } \\
\text { El-Gamil } \\
\text { Alhuria-Port Said }\end{array}$ & $\begin{array}{l}\text { seawater } \\
\text { seawater } \\
\text { sewage }\end{array}$ & $\begin{array}{l}- \\
-\end{array}$ \\
\hline 6 (Temsah) & 31 & 19 & 48 & 32 & 02 & 53 & $\begin{array}{l}\text { El-Dibah } \\
\text { Rattama }\end{array}$ & $\begin{array}{l}\text { seawater } \\
\text { brackish water }\end{array}$ & - \\
\hline 7 (Kassab) & 31 & 16 & 24 & 32 & 05 & 49 & - & - & - \\
\hline 8 (Alhomra) & 31 & 18 & 49 & 32 & 00 & 04 & - & - & - \\
\hline 9 (Elzarka) & 31 & 19 & 09 & 31 & 54 & 25 & \begin{tabular}{|l|} 
Inania \\
Faraskour \\
El-Serw \\
\end{tabular} & $\begin{array}{l}\text { agricultural waste } \\
\text { agricultural waste } \\
\text { agricultural waste }\end{array}$ & $\begin{array}{l}9.81[4] \\
1.64[4]\end{array}$ \\
\hline 10 (Bahr Kromlos)) & 31 & 15 & 51 & 32 & 03 & 23 & - & - & - \\
\hline 11 (Legan) & 31 & 13 & 13 & 32 & 05 & 41 & - & - & - \\
\hline 12 (Deshdy) & 31 & 13 & 40 & 32 & 03 & 08 & \begin{tabular}{|l|} 
El-Gamaliyah \\
El-Matariya
\end{tabular} & $\begin{array}{l}\text { agricultural waste } \\
\text { agricultural waste }\end{array}$ & $\begin{array}{l}- \\
-\end{array}$ \\
\hline
\end{tabular}

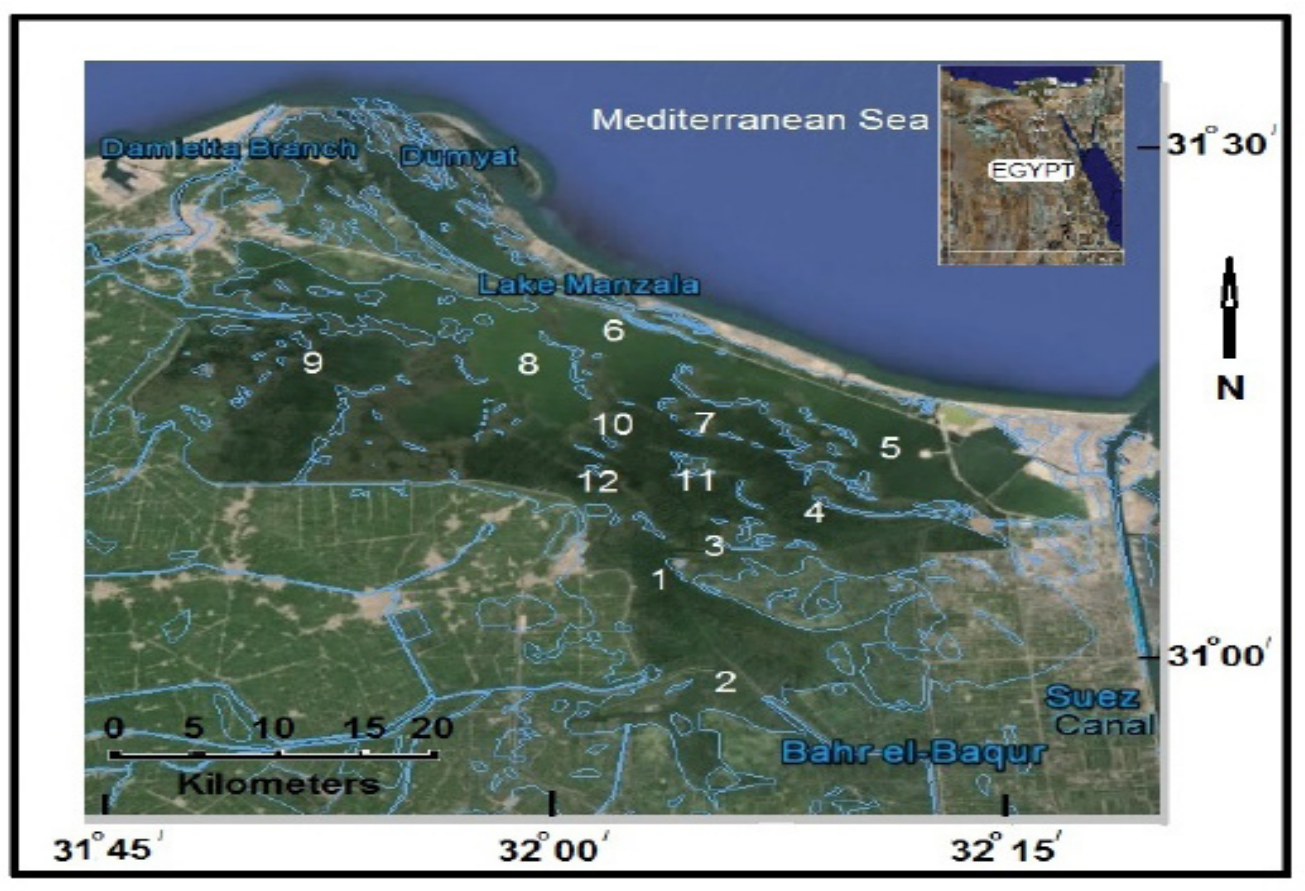

Fig. 1. Map of Manzala Lake showing sampling station. 


\section{Results}

\section{Physicochemical parameters}

Table 2 shows the physicochemical parameters of Manzala Lake during 2015. The temperature ranged between 14 and 27.5. The $\mathrm{pH}$ of water was found to be slightly alkaline throughout the year with the range of 7.65 to 8.88 .

EC strongly varied between the values 1.78 and $29.2 \mathrm{mmhoS} / \mathrm{cm}$ with average values 10.3 and $3.36 \mathrm{mmhoS} / \mathrm{cm}$ during winter and summer, respectively. However, the corresponding median values were 3.71 and $3.15 \mathrm{mmhoS} / \mathrm{cm}$ and the relative standard deviation (RSD) 97.5 and $46.8 \%$, respectively. Also, TDS and salinity varied widely throughout the lake. During winter season, maximum values of TDS and salinity were 18.5 and $19.8 \mathrm{~g} / \mathrm{L}$, in site 5 and minimum values were found to be 1.19 and $1.10 \mathrm{~g} / \mathrm{L}$, respectively, in El Matteria area (site 1). During summer, their maximum values were 4.73 and $4.6 \mathrm{~g} / \mathrm{L}$ in site 6 , respectively, and minimum values were 1.11 and $1.0 \mathrm{~g} / \mathrm{L}$, in site 1 , respectively.
The DO of surface water in Manzala Lake varied widely throughout as can be concluded from its RSD along Manzala Lake. Maximum values of DO during winter and summer were 11.8 and $8.6 \mathrm{mg} / \mathrm{L}$ in site 6 whereas minimum values were 1.6 and $1.25 \mathrm{mg} / \mathrm{L}$ in site 4 .

Maximum values of BOD were 56.8 and 52.8 $\mathrm{mg} / \mathrm{L}$ during winter and summer, respectively in site 1 ; whereas minimum amounts of BOD were found to be 5.76 and $5.2 \mathrm{mg} / \mathrm{L}$ in sites 7 and 6 during winter and summer, respectively. High BOD values $(34.256 .8 \mathrm{mg} / \mathrm{L})$ and low DO levels $(1.25-5.2 \mathrm{mg} / \mathrm{L})$ were observed in sites $1-4$. Average BOD values were 32.1 and $28.9 \mathrm{mg} / \mathrm{L}$ in water and summer, respectively.

Permanganate index of water of Manzala Lake had minimum values of 1.28 and $12.0 \mathrm{mg} / \mathrm{L}$ in sites 12 and $(1 \& 6)$; whereas maximum values were 4.0 and $22.0 \mathrm{mg} / \mathrm{L}$ in sites $(4 \& 5)$ and 5 during winter and summer, respectively. Mean PI values during summer were remarkably higher than during winter.

TABLE 2. Physicochemical parameters of Manzala Lake during 2015.

\begin{tabular}{|c|c|c|c|c|c|c|c|c|c|c|c|c|c|c|c|c|c|c|c|c|}
\hline \multirow{2}{*}{$\begin{array}{l}\text { Parameter } \\
\text { Site }\end{array}$} & \multicolumn{2}{|c|}{$\mathbf{T},{ }^{\circ} \mathbf{C}$} & \multicolumn{2}{|c|}{ pH } & \multicolumn{2}{|c|}{$\begin{array}{c}\text { EC } \\
\mathrm{mmhoS} / \mathrm{cm}\end{array}$} & \multicolumn{2}{|c|}{$\begin{array}{c}\text { TDS } \\
\mathrm{g} / \mathrm{L}\end{array}$} & \multicolumn{2}{|c|}{$\begin{array}{l}\text { Salinity } \\
\%_{0}\end{array}$} & \multicolumn{2}{|c|}{ DO } & \multicolumn{2}{|c|}{ BOD } & \multicolumn{2}{|c|}{ PI } & \multicolumn{2}{|c|}{$\begin{array}{c}\text { Chloride } \\
\left(\mathrm{g} \mathrm{L}^{-1}\right)\end{array}$} & \multicolumn{2}{|c|}{$\begin{array}{c}\text { Alk } \\
\left(\mathrm{mg} \mathrm{CaCO}_{3} \mathrm{~L}^{-1}\right)\end{array}$} \\
\hline & W & $\mathrm{S}$ & W & $\mathrm{s}$ & W & $\mathrm{s}$ & W & $\mathrm{s}$ & W & $\mathrm{s}$ & W & $\mathrm{s}$ & $\mathrm{W}$ & $\mathrm{s}$ & $\mathrm{W}$ & $\mathrm{s}$ & W & $\mathrm{s}$ & W & $\mathrm{s}$ \\
\hline 2 & 14 & 25.5 & 7.80 & 7.78 & 3.39 & 2.82 & 2.02 & 1.63 & 1.90 & 1.50 & 2.64 & 1.68 & 48.0 & 44.24 & 3.60 & 14.8 & 0.900 & 0.655 & 256 & 228 \\
\hline 4 & 14 & 26 & 7.65 & 8.7 & 3.59 & 3.53 & 2.15 & 2.13 & 2.00 & 1.90 & 1.6 & 1.25 & 42.5 & 34.2 & 4.00 & 17.2 & 1.01 & 0.885 & 196 & 193 \\
\hline 5 & 14 & 26 & 7.83 & 8.46 & 29.2 & 3.73 & 18.5 & 2.20 & 19.8 & 2.10 & 9.2 & 4.00 & 18.0 & 17.5 & 4.00 & 22.0 & 13.0 & 0.995 & 127 & 198 \\
\hline 6 & 14 & 26 & 8.88 & 8.48 & 26.0 & 7.90 & 16.4 & 4.73 & 17.3 & 4.60 & 11.8 & 8.60 & 11.2 & 5.20 & 2.80 & 12.0 & 11.9 & 2.63 & 123 & 208 \\
\hline 9 & 14 & 27 & 7.90 & 8.45 & 9.40 & 2.94 & 6.60 & 1.76 & 6.50 & 1.60 & 10.8 & 2.92 & 40.5 & 42.0 & 2.40 & 18.8 & 3.40 & 0.690 & 174 & 180 \\
\hline 10 & 14 & 27.5 & 7.75 & 8.15 & 3.83 & 2.68 & 2.27 & 1.57 & 2.10 & 1.40 & 4.02 & 2.60 & 30.5 & 22.5 & 3.52 & 16.8 & 0.700 & 0.585 & 177 & 192 \\
\hline 11 & 14 & 27.5 & 7.98 & 7.97 & 3.29 & 2.44 & 1.96 & 1.44 & 1.80 & 1.30 & 7.64 & 5.01 & 12.48 & 9.72 & 2.00 & 15.8 & 0.400 & 0.525 & 179 & 208 \\
\hline 12 & 14 & 27.5 & 7.70 & 7.76 & 2.21 & 1.95 & 1.31 & 1.14 & 1.20 & 1.10 & 8.90 & 1.28 & 6.66 & 6.40 & 1.28 & 16.0 & 0.540 & 0.395 & 178 & 182 \\
\hline Mean & 14 & 26.5 & 7.87 & 8.22 & 10.3 & 3.36 & 6.47 & 2.00 & 6.66 & 1.86 & 7.12 & 4.36 & 32.1 & 28.9 & 2.85 & 16.6 & 3.83 & 0.866 & 172 & 201 \\
\hline
\end{tabular}

W, S and Alk denote winter, summer and Alkalinity, respectively. 
Chloride concentration varied widely throughout the lake. Maximum values were 13.0 and $2.63 \mathrm{~g} / \mathrm{L}$ in sites 5 and 6 during winter and summer, respectively. Minimum amounts (0.4 and $0.355 \mathrm{~g} / \mathrm{L}$ ) were recorded in sites 11 and 1 during winter and summer, respectively.

Alkalinity maximum values (256 and 228 $\mathrm{mg} / \mathrm{L}$ ) were recorded in site 2 during winter and summer, respectively. Minimum values (123 and $180 \mathrm{~g} / \mathrm{L}$ ) were recorded in sites 6 and 9 during winter and summer, respectively.

\section{Nutrient levels}

Table 3 shows the variation of major nutrient salts in Manzala Lake during 2015. Ammonia ranged from $6.31 \mu \mathrm{mol} \mathrm{L}{ }^{-1}$ at site 11 to $81.9 \mu \mathrm{mol}$ $\mathrm{L}^{-1}$ at site 4 during winter and from $5.47 \mu \mathrm{mol} \mathrm{L}^{-1}$ at site 9 to $249 \mu \mathrm{mol} \mathrm{L}^{-1}$ at site 5 during summer. The ammonia levels were concentrated in the eastern sites of Manzala Lake.

Nitrite ranged from $2.61 \mu \mathrm{mol} \mathrm{L}^{-1}$ at site 4 to $13.8 \mu \mathrm{mol} \mathrm{L}^{-1}$ at site 3 during winter and from $4.26 \mu \mathrm{mol} \mathrm{L}^{-1}$ at site 9 to $15.1 \mu \mathrm{mol} \mathrm{L} \mathrm{L}^{-1}$ at site 5 during summer. Nitrate ranged from $3.3 \mu \mathrm{mol} \mathrm{L} \mathrm{L}^{-1}$ at site 8 to $24.5 \mu \mathrm{mol} \mathrm{L}{ }^{-1}$ at site 12 during winter and from $0.64 \mu \mathrm{mol} \mathrm{L} \mathrm{L}^{-1}$ at site 2 to $2.84 \mu \mathrm{mol}$ $\mathrm{L}^{-1}$ at site 6 during summer. Average nitrite level during winter was slightly higher than summer. In contrast, average nitrate level in winter is much higher than summer.

Dissolved reactive phosphate ranged from $6.34 \mu \mathrm{mol} \mathrm{L}-1$ at site 6 to $17.7 \mu \mathrm{mol} \mathrm{L}^{-1}$ at site 4 during winter and from $3.47 \mu \mathrm{mol} \mathrm{L}^{-1}$ at site 9 to $22.9 \mu \mathrm{mol} \mathrm{L} \mathrm{L}^{-1}$ at site 5 during summer. Average $\mathrm{PO}_{4}$ level during winter is slightly higher than summer and the fluctuations during summer are apparently higher than winter.

Total Polycyclic aromatic hydrocarbons.

Figure ( $2 a$ and b) shows the TPAHs levels which were generally high in sites close to open seawater inlets during winter and low during summer. Maximum value of TPAHs during winter was $4.75 \mu \mathrm{g} / \mathrm{L}$ in site 11 whereas minimum value was $0.512 \mu \mathrm{g} / \mathrm{L}$ recorded in site 2. Maximum value of TPAHs, during summer, was $2.68 \mu \mathrm{g} / \mathrm{L}$ in site 1 whereas minimum value was $0.25 \mu \mathrm{g} / \mathrm{L}$ in site 5. Average TPAHs values during winter $(2.39 \mu \mathrm{g} / \mathrm{L})$ was higher than during summer $(1.85$ $\mu \mathrm{g} / \mathrm{L})$.

TABLE 3. Nutrient salts of water collected from Manzala Lake during 2015.

\begin{tabular}{|c|c|c|c|c|c|c|c|c|}
\hline \multirow{3}{*}{$\begin{array}{c}\text { Parameter } \\
\text { Site }\end{array}$} & \multicolumn{2}{|c|}{ ammonia } & \multicolumn{2}{|c|}{ nitrite } & \multicolumn{2}{|c|}{ nitrate } & \multicolumn{2}{|c|}{ phosphate } \\
\hline & \multicolumn{8}{|c|}{$\mu \mathrm{mol} \mathrm{L} \mathrm{L}^{-1}$} \\
\hline & $\mathrm{W}$ & $\mathrm{S}$ & $\mathrm{W}$ & $S$ & $\mathrm{~W}$ & $\mathrm{~S}$ & $\mathrm{~W}$ & $\mathrm{~S}$ \\
\hline 1 & 67.0 & 41.2 & 9.23 & 4.96 & 19.9 & 2.08 & 9.03 & 9.50 \\
\hline 2 & 59.9 & 48.1 & 10.9 & 5.05 & 16.9 & 0.64 & 14.7 & 12.5 \\
\hline 3 & 41.7 & 89.9 & 13.8 & 4.63 & 24.0 & 1.00 & 10.1 & 9.79 \\
\hline 4 & 81.9 & 248 & 2.61 & 4.96 & 8.63 & 1.44 & 17.7 & 19.9 \\
\hline 5 & 28.2 & 249 & 3.98 & 15.1 & 4.43 & 2.20 & 11.7 & 22.9 \\
\hline 6 & 8.19 & 14.8 & 3.49 & 5.01 & 4.43 & 2.84 & 6.34 & 5.86 \\
\hline 7 & 10.4 & 9.07 & 7.13 & 6.36 & 19.6 & 2.20 & 9.79 & 6.07 \\
\hline 8 & 14.7 & 6.97 & 3.86 & 4.91 & 3.30 & 1.20 & 8.92 & 4.87 \\
\hline 9 & 12.2 & 5.47 & 5.45 & 4.26 & 8.16 & 1.44 & 11.3 & 3.47 \\
\hline 10 & 13.8 & 7.51 & 8.59 & 4.68 & 20.7 & 0.96 & 9.55 & 5.37 \\
\hline 11 & 6.31 & 5.89 & 3.60 & 6.55 & 23.0 & 1.24 & 9.76 & 5.16 \\
\hline 12 & 33.6 & 23.4 & 8.18 & 8.28 & 24.5 & 1.44 & 8.79 & 7.19 \\
\hline Mean & 31.5 & 62.4 & 6.74 & 6.23 & 14.8 & 1.56 & 10.6 & 9.38 \\
\hline
\end{tabular}

$\mathrm{W}$ and $\mathrm{S}$ denote winter and summer, respectively. 

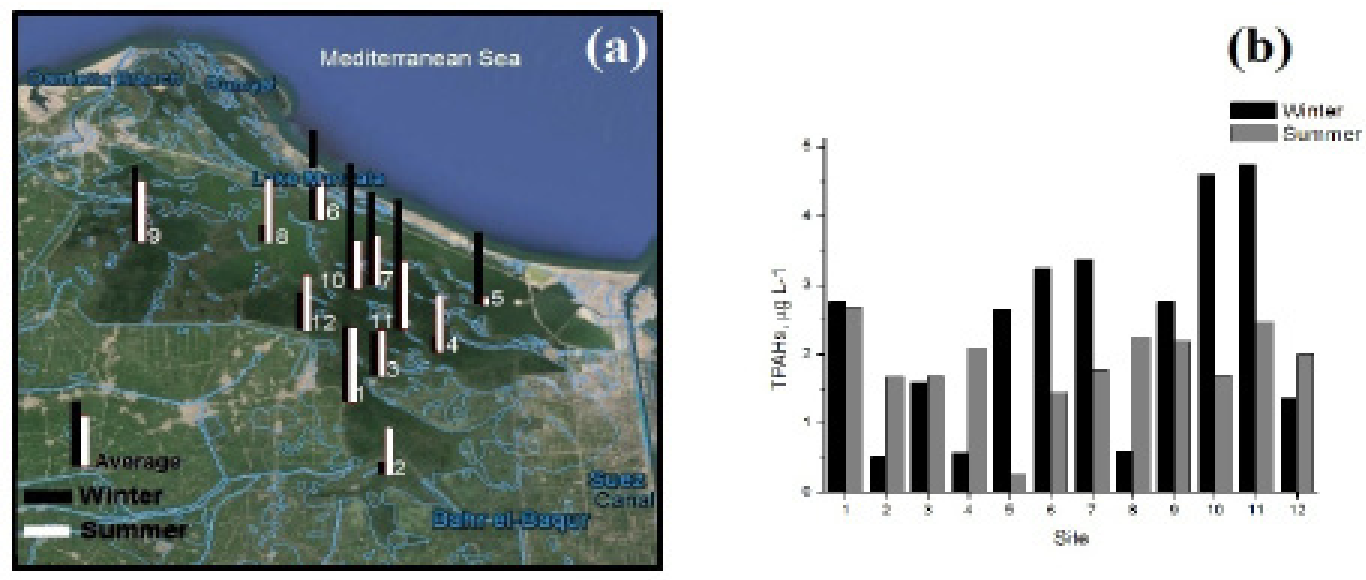

Fig. 2. Relative variation of TPAHs ratio in Manzala Lake during winter (black) and summer (gray).

\section{Statistical correlation}

The Pearson correlation co-efficient (PC) among various water quality parameters are given in Table 4. Matrix analysis showed that there were highly significant positive correlations $(\mathrm{P} \leq 0.01)$ between EC vs. TDS, salinity and chloride; TDS vs. salinity and chloride; salinity vs. chloride; and ammonia and TIN during the studied seasons. Also, significant positive correlations $(0.01<\mathrm{P}<0.05)$ were found between DO vs. EC, TDS, salinity and $\mathrm{Cl}$ during the same period. On contrary, significant negative correlations were detected between DO and BOD during winter and summer.

During winter, highly significant positive correlations were detected between $\mathrm{PO}_{4}$ vs. ammonia and TIN whereas a highly significant negative correlation was observed between nitrite and TPAHs.

During summer, the bi-variants PI vs. BOD and TIN vs. BOD were highly positively correlated whereas alkalinity vs. EC, TDS, salinity; DO and $\mathrm{Cl}$; DO vs. ammonia and TIN; and nitrate vs. EC, TDS, salinity and $\mathrm{Cl}$ were highly negatively correlated.

Significant positive correlations $(0.01<\mathrm{P}<$ 0.05 ) were found between the parameters nitrite vs. $\mathrm{PO}_{4}$; $\mathrm{DO}$ and nitrate vs. EC, TDS, salinity and chloride during winter and between the parameters: $\mathrm{pH}$ vs. chloride; alkalinity vs. TIN and $\mathrm{PO}_{4}$; and ammonia vs. $\mathrm{BOD}, \mathrm{PI}$ and $\mathrm{PO}_{4}$ during summer. Moreover, significant inverse correlations were detected between DO vs. BOD, $\mathrm{PI}$ and $\mathrm{PO}_{4}$; ammonia vs. TPAHs; and TIN vs. EC, TDS, salinity and chloride during summer.

\section{Discussion}

Manzala Lake receives large amounts of untreated sewage and irrigation returns (ca. 3 milliard $\mathrm{m}^{3}$ annually) from five major governorates located in the northern of Egypt; Damietta, Dakahlia, Sharkiya, Ismailia and Port Said [4]. In addition, the gross area of the lake was reduced as estimated by satellite images during 1973 - 2013 from 1,100 km2 in 1973 to $1052 \mathrm{~km}^{2}$ in 1984 , to $720 \mathrm{~km}^{2}$ in 2003 and finally became $385 \mathrm{~km}^{2}$ in $2013[5,18]$. They attributed this shrinking to the reclamation activities and to the construction of the coastal highway. This is affirmed by the gradual decrease in wet lands pictured by goggle maps within the period 1972 - 2015 (Fig. 3). This continuously changing morphology of Manzala Lake has direct impact on its water quality and may lead to many side effects to the consumers which made continuous monitoring of water quality a mandate.

\section{Physicochemical parameters}

The $\mathrm{pH}$ of water samples was within the prescribed limits, i.e. 6.5 to $9.0[19,20]$. The $\mathrm{pH}$ values were generally high in northern sites influenced by the inflows from the seawater inlets especially during winter. It is known that during winter, a water block of fresh water flow during January is annually scheduled causing inflows from seawater to be highly effective [21]. However, $\mathrm{pH}$ in sites 6 (during winter), 4, 7 and 8 (during summer) were slightly higher than common $\mathrm{pH}$ values in coastal seawater (8-8.5) indicating a probable state of eutrophication [20]. This can be supported by the observation of higher average $\mathrm{pH}$ value during summer than winter as the growth of aquatic organisms flourishes in worm weather at $\mathrm{pH}$ values ranging from 6.5-8.5 [20]. So the water was conducive for growth of water organisms. 
TABLE 4. Pearson bivariate correlation co-efficient of water quality parameters in Manzala Lake during 2015.

\begin{tabular}{|c|c|c|c|c|c|c|c|c|c|c|c|c|c|c|c|c|}
\hline \multicolumn{17}{|c|}{ Winter correlations } \\
\hline & & $\mathrm{pH}$ & $\mathrm{EC}$ & TDS & Sal & Do & BOD & PI & $\mathrm{Cl}$ & Alk & $\mathrm{Amm}$ & $\mathrm{NO}_{2}$ & $\mathrm{NO}_{3}$ & TIN & $\mathrm{PO}_{4}$ & TPAHs \\
\hline \multirow[t]{2}{*}{$\mathrm{pH}$} & PC & & 0.52 & 0.53 & 0.50 & 0.48 & -0.32 & 0.33 & 0.47 & -0.03 & 0.35 & 0.08 & 0.44 & 0.35 & 0.20 & -0.24 \\
\hline & $\mathrm{St2}$ & & 0.086 & 0.080 & 0.098 & 0.117 & 0.309 & 0.294 & 0.121 & 0.923 & 0.264 & 0.806 & 0.153 & 0.266 & 0.540 & 0.445 \\
\hline \multirow[t]{2}{*}{$\mathrm{EC}$} & PC & & & $1.00^{-\prime}$ & $1.00^{* * *}$ & $0.67^{\circ}$ & -0.35 & -0.18 & $0.997^{\prime \prime}$ & 0.31 & 0.05 & -0.03 & $0.61^{\circ}$ & 0.05 & 0 & -0.41 \\
\hline & $\mathrm{St2}$ & & & 0.000 & 0.000 & 0.017 & 0.269 & 0.577 & 0.000 & 0.325 & 0.876 & 0.939 & 0.035 & 0.870 & 0.999 & 0.180 \\
\hline \multirow[t]{2}{*}{ TDS } & PC & & & & $1.00^{\circ \prime}$ & $0.67^{\circ}$ & $\begin{array}{ll}-0.34 \\
\end{array}$ & -0.19 & $0.997^{\prime \prime}$ & 0.30 & 0.05 & -0.03 & $0.63^{\circ}$ & 0.05 & -0.00 & -0.40 \\
\hline & $\mathrm{st2}$ & & & & 0.000 & 0.017 & 0.279 & 0.561 & 0.000 & 0.346 & 0.874 & 0.918 & 0.030 & 0.869 & 0.995 & 0.197 \\
\hline \multirow[t]{2}{*}{ Sal } & PC & & & & & $0.67^{\circ}$ & -0.36 & -0.20 & $0.999^{-\prime}$ & 0.29 & 0.04 & -0.01 & $0.65^{\circ}$ & 0.04 & -0.01 & -0.41 \\
\hline & $\mathrm{St2}$ & & & & & 0.018 & 0.256 & 0.543 & 0.000 & 0.361 & 0.900 & 0.983 & 0.023 & 0.891 & 0.988 & 0.181 \\
\hline \multirow[t]{2}{*}{ DO } & $\mathrm{PC}$ & & & & & & $-0.62^{2}$ & -0.07 & $0.65^{\circ}$ & 0.48 & -0.33 & -0.02 & 0.47 & -0.32 & -0.38 & -0.14 \\
\hline & $\mathrm{st2}$ & & & & & & 0.031 & 0.828 & 0.021 & 0.114 & 0.300 & 0.941 & 0.119 & 0.314 & 0.228 & 0.665 \\
\hline \multirow[t]{2}{*}{ BOD } & PC & & & & & & & -0.03 & -0.34 & -0.15 & 0.21 & -0.33 & -0.36 & 0.19 & 0.23 & 0.20 \\
\hline & $\mathrm{St2}$ & & & & & & & 0.927 & 0.282 & 0.646 & 0.519 & 0.300 & 0.254 & 0.555 & 0.466 & 0.545 \\
\hline \multirow[t]{2}{*}{$\mathrm{PI}$} & PC & & & & & & & & -0.23 & -0.10 & 0.48 & 0.55 & -0.14 & 0.49 & 0.39 & -0.55 \\
\hline & St2 & & & & & & & & 0.478 & 0.748 & 0.115 & 0.065 & 0.657 & 0.108 & 0.208 & 0.063 \\
\hline \multirow[t]{2}{*}{$\mathrm{Cl}$} & PC & & & & & & & & & 0.29 & 0.03 & -0.02 & $0.64^{\circ}$ & 0.04 & -0.01 & -0.40 \\
\hline & $\mathrm{St2}$ & & & & & & & & & 0.368 & 0.918 & 0.946 & 0.027 & 0.910 & 0.975 & 0.198 \\
\hline \multirow[t]{2}{*}{ Alk } & PC & & & & & & & & & & -0.10 & -0.09 & -0.18 & -0.11 & 0.02 & -0.18 \\
\hline & $\mathrm{St2}$ & & & & & & & & & & 0.748 & 0.774 & 0.577 & 0.742 & 0.960 & 0.571 \\
\hline \multirow[t]{2}{*}{$\mathrm{NH}_{4}$} & PC & & & & & & & & & & & 0.55 & 0.11 & $1.00^{-\prime}$ & $0.96^{\prime \prime}$ & -0.52 \\
\hline & $\mathrm{St2}$ & & & & & & & & & & & 0.065 & 0.729 & 0.0000 & 0.000 & 0.082 \\
\hline \multirow[t]{2}{*}{$\mathrm{NO}_{2}$} & PC & & & & & & & & & & & & 0.33 & 0.57 & $0.60^{\circ}$ & $-0.73^{\prime \prime}$ \\
\hline & $\mathrm{St2}$ & & & & & & & & & & & & 0.298 & 0.051 & 0.037 & 0.007 \\
\hline \multirow[t]{2}{*}{$\mathrm{NO}_{3}$} & PC & & & & & & & & & & & & & 0.13 & $\begin{array}{l}0.09 \\
\end{array}$ & -0.28 \\
\hline & $\mathrm{St2}$ & & & & & & & & & & & & & 0.694 & 0.772 & 0.374 \\
\hline \multirow[t]{2}{*}{ TIN } & PC & & & & & & & & & & & & & & $0.96^{\prime \prime}$ & -0.54 \\
\hline & $\mathrm{S} 12$ & & & & & & & & & & & & & & 0.000 & 0.071 \\
\hline \multirow[t]{2}{*}{$\mathrm{PO}_{4}$} & PC & & & & & & & & & & & & & & & -0.57 \\
\hline & $\mathrm{St2}$ & & & & & & & & & & & & & & & 0.054 \\
\hline \multirow[t]{2}{*}{ TPAHs } & PC & & & & & & & & & & & & & & & \\
\hline & $\mathrm{St2}$ & & & & & & & & & & & & & & & \\
\hline
\end{tabular}

\begin{tabular}{|c|c|c|c|c|c|c|c|c|c|c|c|c|c|c|c|c|}
\hline \hline \multicolumn{10}{|l|}{ TABLE 4. (continued) } \\
\hline
\end{tabular}




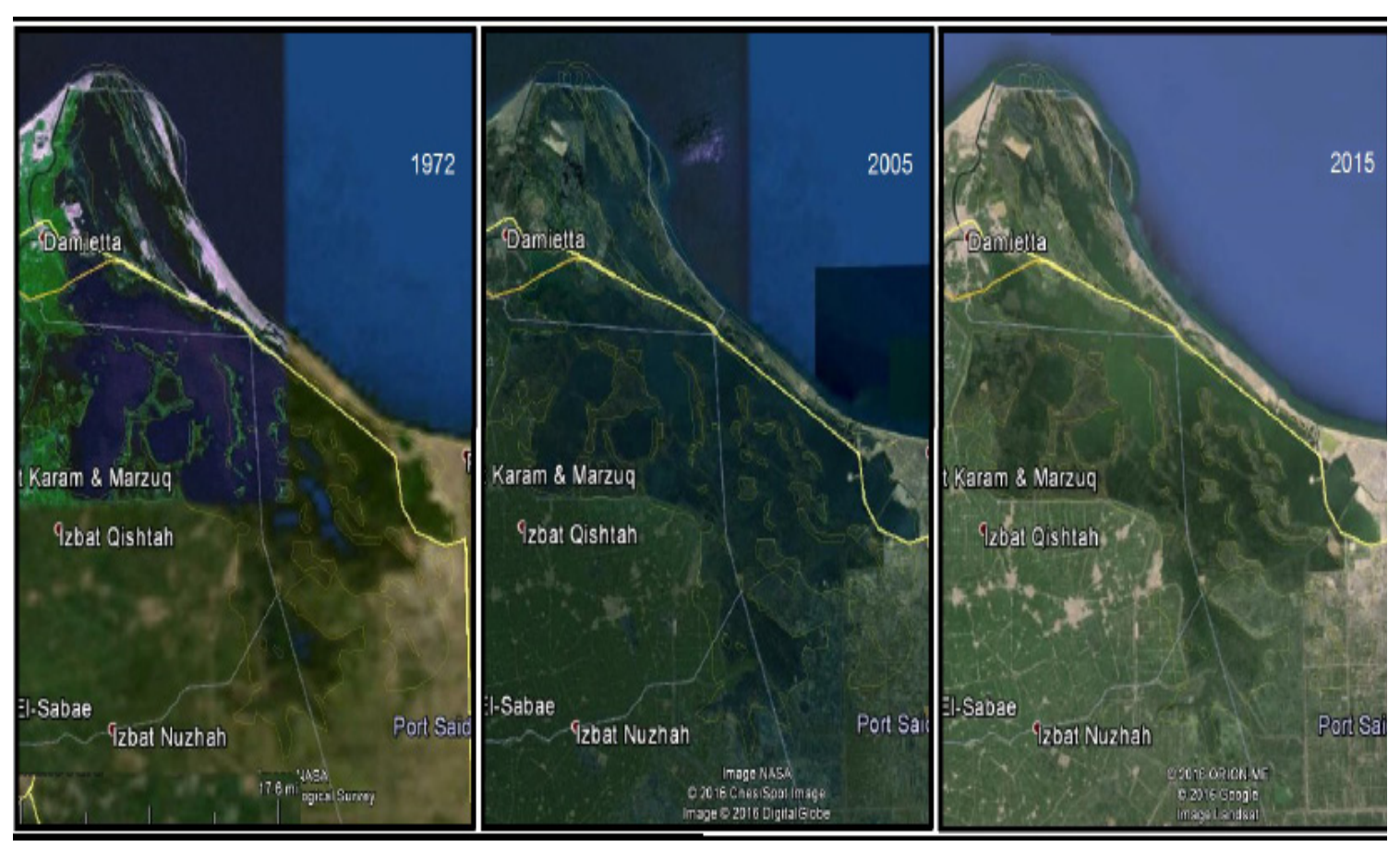

Fig. 3. Variation of vegetation in Manzala Lake during the period 1972-2015.

The RSD values of EC indicate that the levels of EC and their fluctuations during winter were more than summer due to the river block during winter. For the same reason, the northern sites were strongly influenced by the seawater inflows during winter as shown in Fig. 4. Also, TDS and salinity were affected by the sea inlet area at El Gamil. The degree of salinity of lake water indicated that it was brackish all over the lake according to 'Phocaides' classification [22].

The highly significantpositive correlations ( $\mathrm{P}$ $=<0.01$ ) observed between EC, TDS, salinity and chloride concentration approaching unity confirm the credibility of EC and salinity measurements as they are mathematically correlated. Also, these highly significant correlations may indicate that the source of chloride content is mainly the seawater as concluded from their high values in sites near seawater inlets (Fig. 4). Moreover, the highly significant correlation between EC and TDS indicated that the dissolved solids were mainly ionic.

DO is the extent of the quantity of oxygen freely available in water. It figured out the possibilities for flora and fauna living in the water system. The concentration of DO is controlled by its consumption by aerobic organisms and plants which is reproduced during photosynthesis. Also,
DO levels may change by variations in natural reiteration, temperature, flow, and depth. Level of DO was found to be mainly affected by the type of nearest water effluents (Fig. 5). In DOpoor sites such as near outlets of Bahr El Baqur drain, anaerobic conditions should set in and remaining organic matter may undergo anaerobic decomposition to yield products such as methane and ammonia [7]. That may also explain the observed high concentration of ammonia in the eastern region of the lake especially site 4 (Fig. 6). At temperatures $14-28{ }^{\circ} \mathrm{C}$, the maximum detected level of $\mathrm{DO}$ $(11.8$ and $8.6 \mathrm{mg} / \mathrm{L})$ is $111-113 \%$ supersaturated that means a potential sign of a mild unhealthy eutrophication. Mean values of DO was within the recommended limits ( $\geq 4 \mathrm{mg} / \mathrm{L}$ or $30 \%$ saturation) for most Manzala Lake fish species although it was less than optimum value ( $\geq 5 \mathrm{mg} / \mathrm{L})[19]$.

Average BOD values were high compared to the adopted limits in Europe (BOD of salmonid waters should be $\leq 3 \mathrm{mg} \mathrm{O}_{2} \mathrm{l}^{-1}$, and $\leq 6 \mathrm{mgO}_{2} \mathrm{l}^{-1}$ for cyprinid waters [7]. High BOD values in the eastern sites of Manzala Lake may suggest an anaerobic decomposition of ammonia and organic materials in industrial and municipal effluents and production of organic material in the lake itself that may be lethal for fish [23]. 


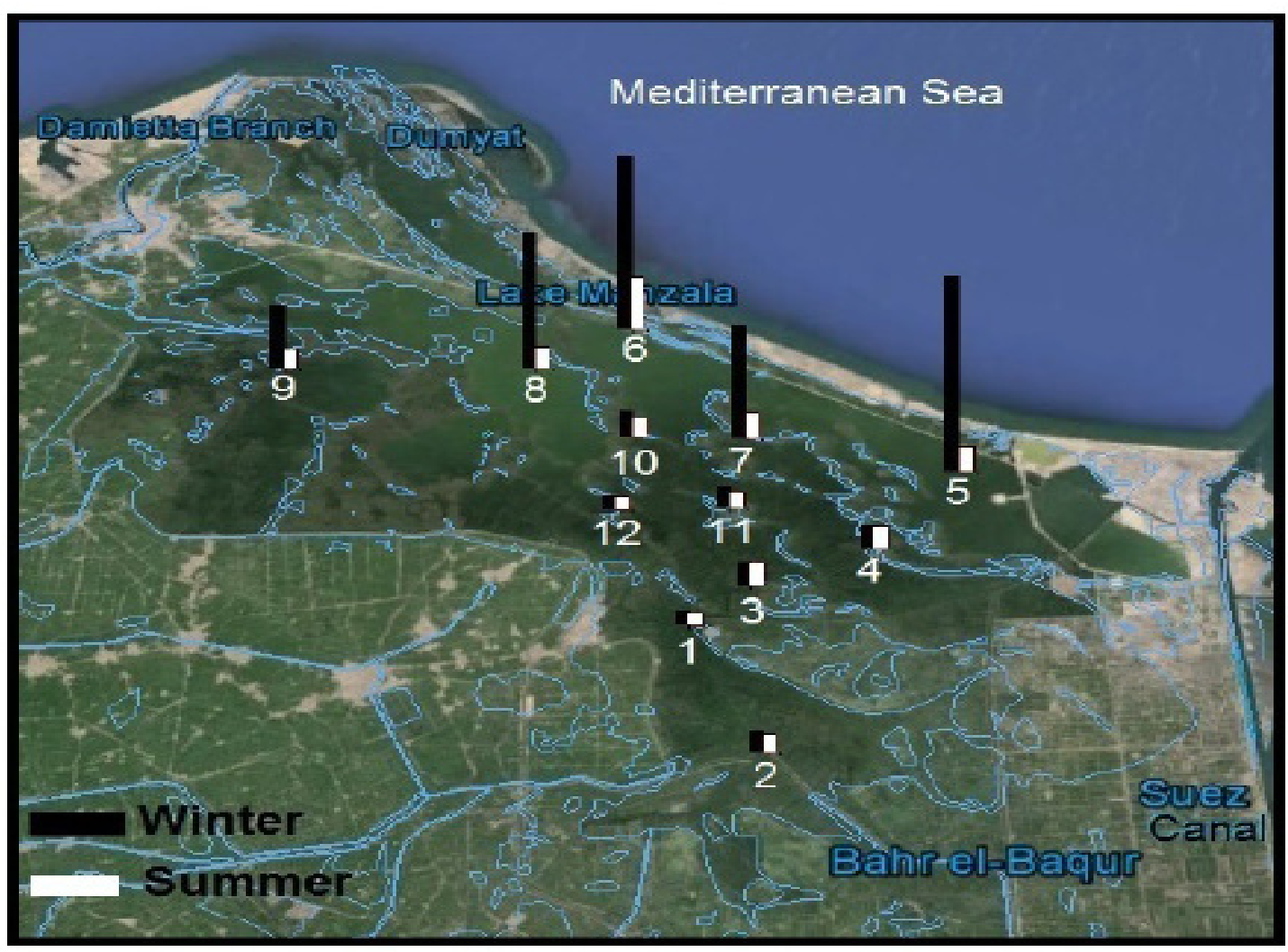

Fig. 4. Relative variation of EC in Manzala Lake during winter and summer, 2015.

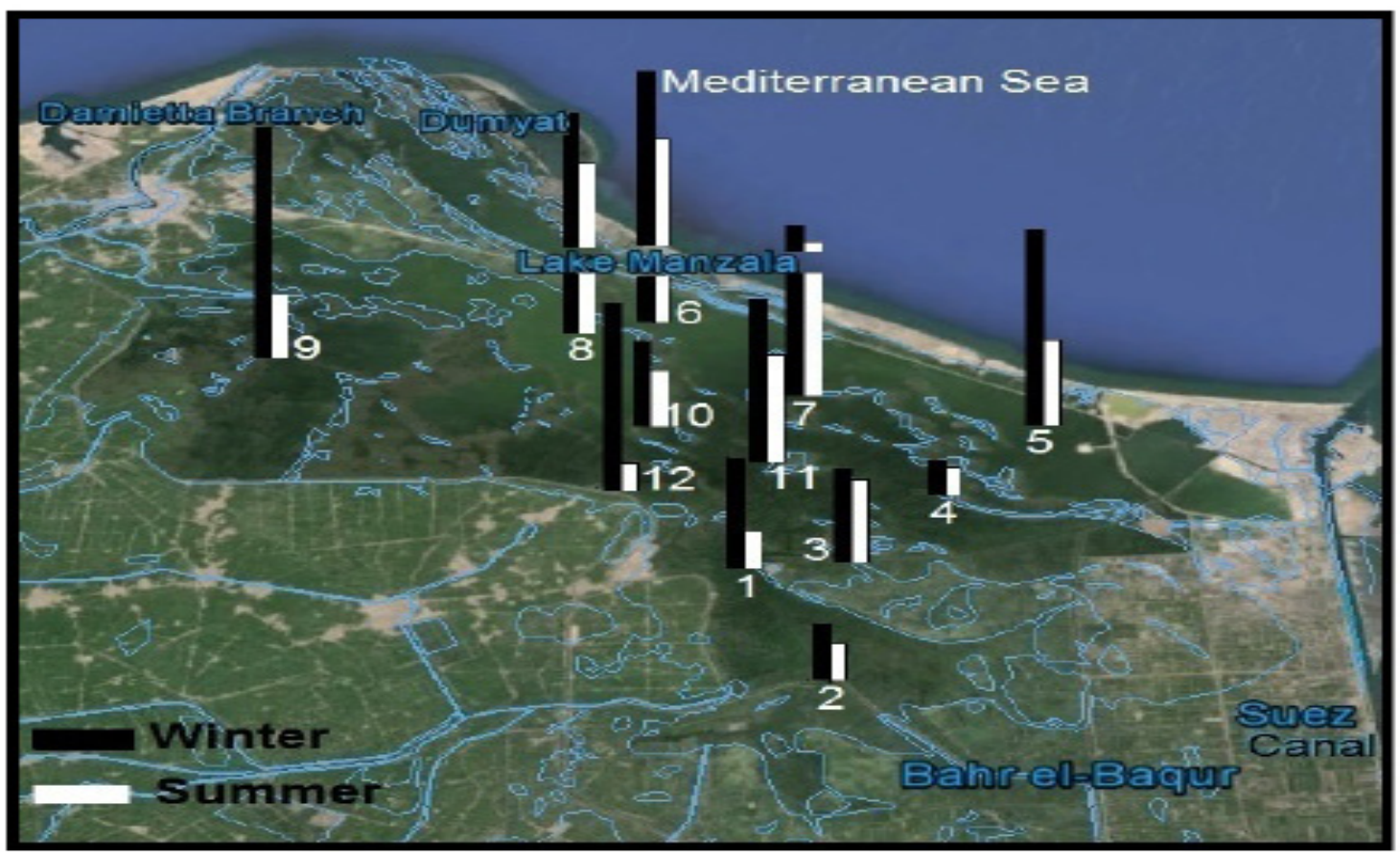

Fig. 5. Relative variation of DO in Manzala Lake during winter and summer, 2015.

Egypt. J. Chem. 60, No. 4 (2017) 
As PI refers only to $40 \%$ of the total of chemical oxygen demand (COD) [24], the presence of its maxima at site 5 during winter and summer may be related to the presence of high chloride contents which may interfere with the oxydisable organic matter. The observed increase of PI average during summer, in comparison to winter, may be attributed to the influence of large drain loads during summer compared with winter due to water block of river Nile during winter.

Alkalinity is involved in the consequential effects of eutrophication of waters. Wherever a high degree of photosynthesis occurs, a high consumption of carbon dioxide is expected by algae and $\mathrm{pH}$ increases via left-right shifts of a series of related chemical equilibrium reactions, as follows [20]:

$$
\begin{aligned}
& \mathrm{H}+\mathrm{HCO}_{3}{ }^{-} \rightleftharpoons \mathrm{H}_{2} \mathrm{CO}_{3}\left(\mathrm{H}_{2} \mathrm{O}+\mathrm{CO}_{2}\right) \\
& \mathrm{H}^{+}+\mathrm{CO}_{3}^{2-} \rightleftharpoons \mathrm{HCO}_{3}^{-} \\
& \mathrm{H}_{2} \mathrm{O} \rightleftharpoons \mathrm{H}^{+}+\mathrm{OH}^{-}
\end{aligned}
$$

Consequently, the relative increase in alkalinity during summer, compared with winter and in the south and south eastern sites in Manzala Lake, may be attributed to a state of eutrophication processes. This was also confirmed by the significant correlations $(0.01<\mathrm{P}<0.05)$ found between alkalinity vs. DO, chloride, EC, TDS, salinity, TIN and $\mathrm{PO}_{4}$ which is attributed to a state of eutrophication during winter.

\section{Nutrient levels}

The observed higher average ammonia level during summer compared with winter is attributed to the higher inflows of nutrient-rich effluents and the relatively higher evaporation rate during summer compared with winter affected with water block [21]. The high ammonia levels in the eastern sites of the lake is influenced by the domestic and agricultural effluents of the major drains such as Bahr El Baqur, El Matteria, Hadus and Ramsis (Fig. 6).

The maximum allowed limit of total ammonia decreases with increasing temperature and $\mathrm{pH}$ values as illustrated in Table 5. The release of the toxic free ammonia increases with $\mathrm{pH}\left(-\log \left[\mathrm{H}^{+}\right]\right)$ according to the equation [20]:

$\mathrm{NH}_{4}^{+} \rightleftharpoons \mathrm{NH}_{3}+\mathrm{H}^{+}$

Consequently, total ammonia concentration in Manzala Lake can be considered tolerable during winter. On contrary, during summer, sites $2-6$ exceeded the allowed limits especially in site 4 that reached ca 30 times the allowed limit, influenced

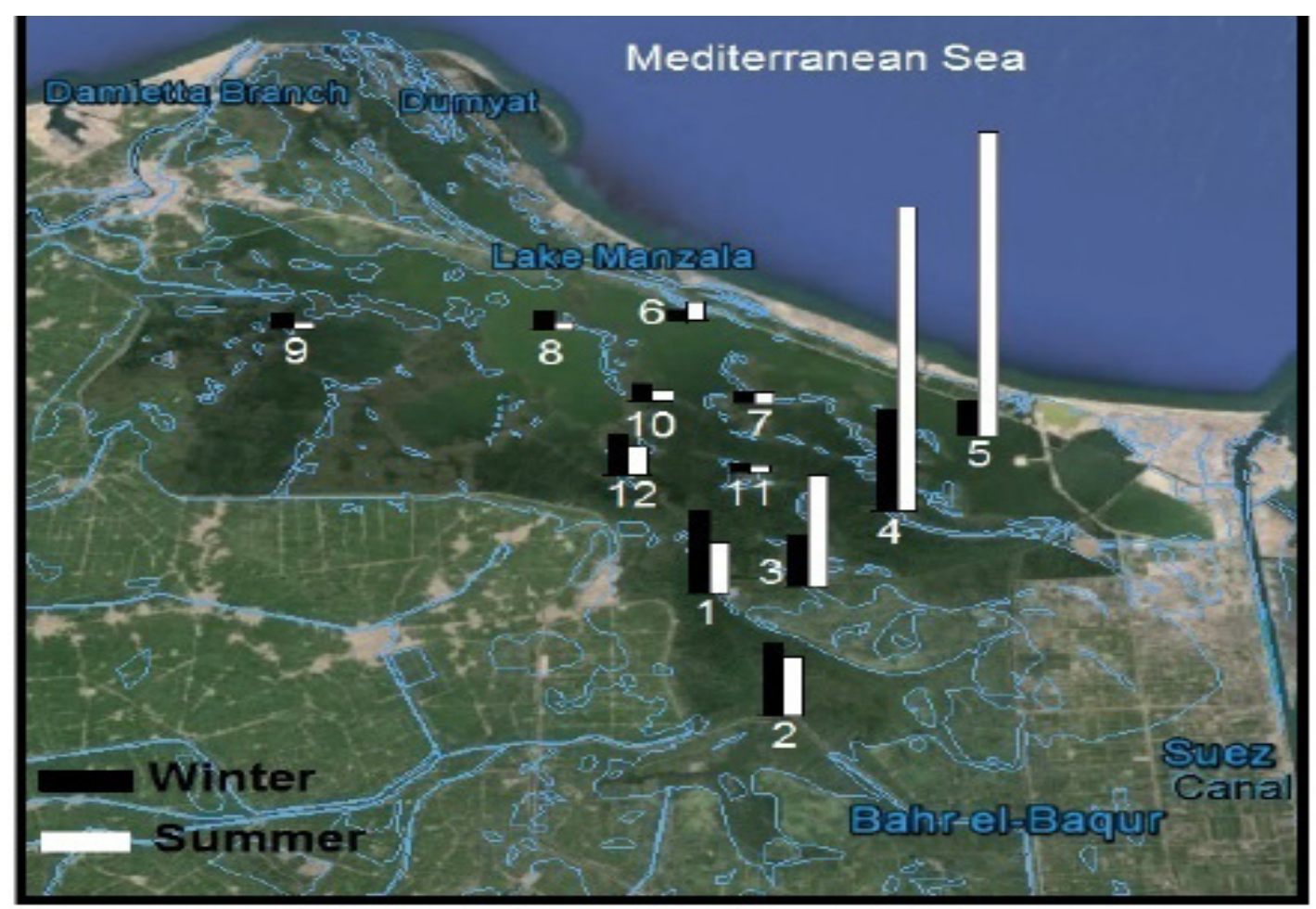

Fig. 6. Relative variation of ammonia in Manzala Lake during winter and summer 2015. 
TABLE 5. Maximum allowed limits of ammonia $\left(\mu \mathrm{mol} \mathrm{L}^{-1}\right)$ for an aquatic life at different water $\mathrm{pH}$ and temperatures within present study parameters [20]

\begin{tabular}{|c|c|c|c|c|}
\hline $\mathrm{pH}$ & $10^{\circ} \mathrm{C}$ & $15^{\circ} \mathrm{C}$ & $25^{\circ} \mathrm{C}$ & $30^{\circ} \mathrm{C}$ \\
\hline 7.50 & 129 & 129 & 61.8 & 43.5 \\
\hline 7.75 & 124 & 118 & 58.2 & 41.8 \\
\hline 8.00 & 80.6 & 78.2 & 38.8 & 27.6 \\
\hline 8.25 & 45.9 & 44.7 & 22.9 & 16.5 \\
\hline 8.50 & 26.5 & 25.9 & 13.5 & 10 \\
\hline 8.75 & 15.3 & 15.9 & 9.41 & 6.47 \\
\hline
\end{tabular}

by Bahr El Baqur effluents. This should be fatal for fish and aquatic life as a whole in this sector.

Most $\mathrm{NO}^{2-}$ levels including average value were higher than the maximum allowed maximum nitrite concentration; $4.35 \mu \mathrm{mol} \mathrm{L}^{-1}$ [19]. All nitrate levels were much lower than the allowed maximum nitrate concentration; $48.4 \mu \mathrm{mol} \mathrm{L}^{-1}$ [19].

Comparing the annual average concentration of $\mathrm{N}$-ions, a sequence of decrease of them was observed to be ammonium $>>$ nitrate $>$ nitrite, which may suggest an oxygen-deficiency state.

Most PO4 levels were higher than the maximum allowed concentration; $4.35 \mu \mathrm{mol} \mathrm{L} \mathrm{L}^{-1}$ [19]. A comparison between the levels of ammonia, nitrite, nitrate and $\mathrm{PO}_{4}$ in Manzala Lake (Fig. 6-8) indicated that the sources of pollution are drains found in the eastern and south eastern sectors of the lake especially Bahr El Baqur during summer.

The observed higher averages of oxygenated nutrients during winter compared with summer may be correlated with the shortage in fresh water inflows concomitant with winter block. The winter block cannot actually be correlated with these ions but it just discloses their main sources which are apparently agricultural waste effluents.

The average total inorganic nitrogen (TIN) values (53.0 and $70.2 \mu \mathrm{mol} \mathrm{L}^{-1}$ ) during winter and summer, respectively; indicated that Manzala Lake was Class III eutrophic, according to Standard Statistical Classification of Surface Freshwater Quality for the Maintenance of Aquatic Life [25]. Concentrations of hazardous substances in Class III can be detected but the concentrations should be below chronic and acute values.

As the principal nutrients entering the Manzala Lake are inorganic phosphorus and nitrogen, their ratio is necessary to be controlled for the development of the undesirable growths associated with eutrophication [26]. Therefore, the N/P ratio has been calculated from the lake data for total inorganic nitrogen as ammonia, nitrite and nitrate and phosphorus (as orthophosphate) which was found to be within 2.28-10.6 during winter and 2.46-12.8 during summer. The relative importance of nitrogen and phosphorus to phytoplankton productivity was reported [27]. It is well known that the growth and proliferation of aquatic plants is a result of the utilization and assimilation of organic materials through the photosynthesis. Thus the plant biomass increases by the uptake of available phosphorus and nitrogen from the water. It was also found that the nutrient that will control the maximum amount of plant biomass is the nutrient that "runs off" or reaches a minimum before other nutrient. Therefore under a certain condition, nitrogen may reach a minimum value before phosphorus and, as a result, control the maximum amount of plant biomass and vice versa. This situation depends on the relative amount of nitrogen and phosphorus required by aquatic plants and their availability in water body. Accordingly, a mass ratio of available forms of inorganic nitrogen and phosphorus $(\mathrm{N} / \mathrm{P})$ were used to calculate the limiting nutrient in water. In this respect, different ratios were suggested by many authors [28-30]. The most conservative ratio suggests that when $\mathrm{N} / \mathrm{P}$ ratio is between 5 and 10, either nutrient could be limiting and if less than 5 , nitrogen is the limiting for plant growth. The N/P ratio in Manzala Lake was below 5 indicating that nitrogen is the limiting nutrient except for sites 2-4 and 12 during winter, 1 and 3 during summer that were within 5 and 10 . This may explain the significant correlation between TIN and BOD during summer. Also, sites 1 during winter, and 4 and 5 during summer were slightly higher than 10 , that means that phosphorous in these sites is the limiting nutrient. However, average N/P ratios were 5 and 7.48 during winter and summer, respectively. As most lake sites are characteristic with low N/P ratios, it may favor green algal dominance, macrophytes and zooplankton [31.32].

\section{Total Polycyclic aromatic hydrocarbons}

TPAHs has been defined as the concentration of six specific compounds: fluoranthene, 3,4benzofluoranthene,11,12-benzofluoranthene, 3,4benzopyrene,1,12-benzoperyleneand indeno (1,2,3cd)pyrene which are carcinogens of greater or lesser potency [7]. TPAHs are higher than permitted value $(<1 \mu \mathrm{g} / \mathrm{L})$ [7]. The observed high TPAHs levels in sites of Manzala Lake close to open seawater inlets during winter (Fig. 2) indicated that its main source may be harbor activities. The inverse of this behavior occurring during summer may indicate that the TPAHs loads of the lake drains have greater effect than the harbor activities despite the finding of the TPAHs average during summer is lower than during winter. This should be attributed to the dilution effect of effluent inflows during summer compared with winter during which a block of water flow is regularly scheduled [21].

Egypt. J. Chem. 60, No. 4 (2017) 

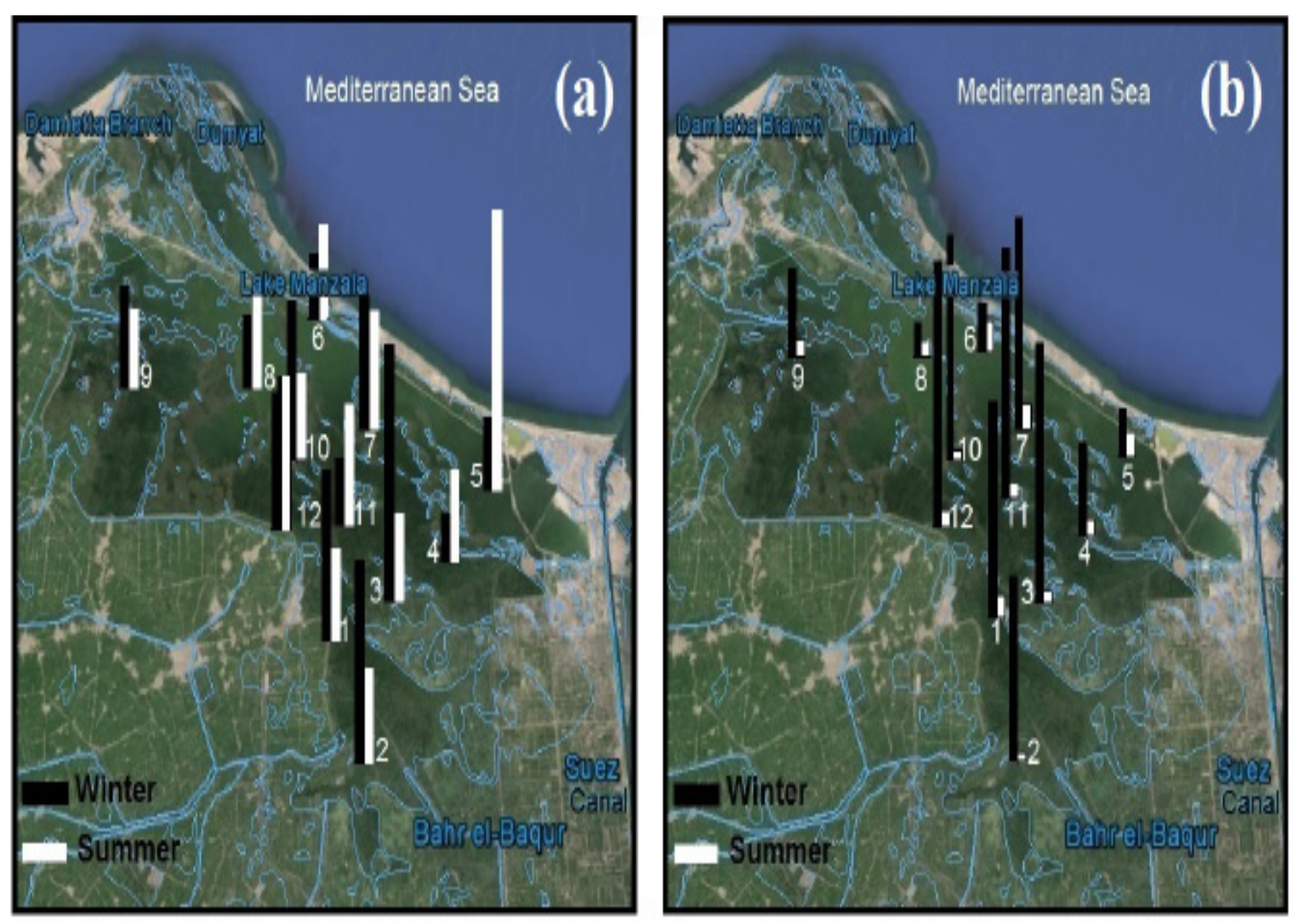

Fig. 7. Relative variation of nitrite (a) and nitrate (b) in Manzala Lake during 2015.

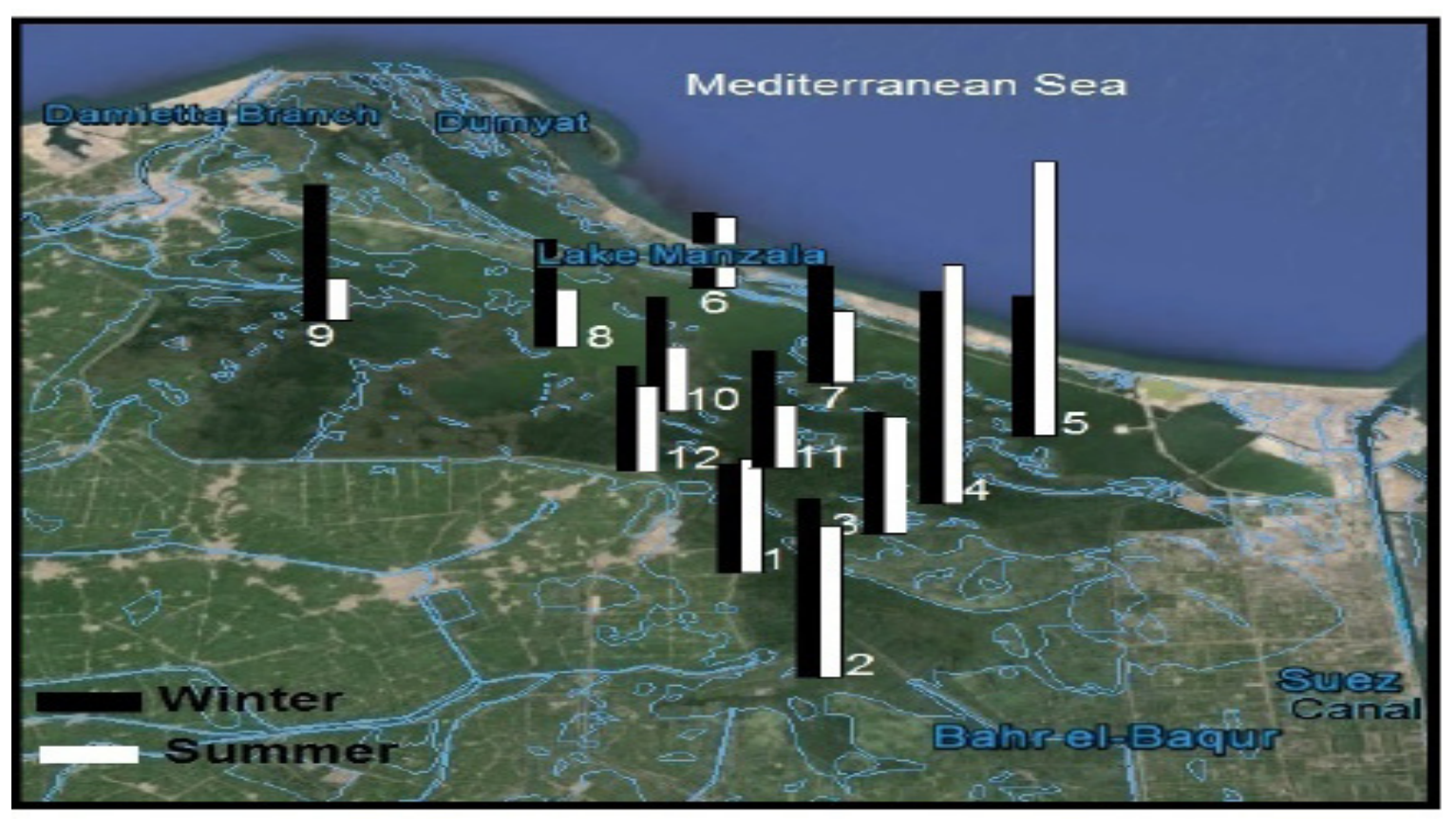

Fig. 8. Relative variation of PO4 in Manzala Lake during 2015. 


\section{Statistical correlation}

Matrix analysis (Table 4) showed that significant correlations could be detected between the studied parameters during summer more than during winter which may be due to the influence of winter water block that decreases the homogeneity of water of the Manzala Lake which transforms to isolated ponds-like during winter [21]. The highly significant correlation between ammonia and TIN indicated that ammonia was the major component of TIN.

The observed significant positive correlations between DO vs. EC, TDS, salinity and $\mathrm{Cl}$ are unexpected as they do not obey Henry's law; the higher the salinity level, the lower the dissolved oxygen concentration [33]. This may be explained in view of the observed inverse correlation between $\mathrm{DO}$ and BOD which is attributed to the consumption of DO by microorganism such as aerobic bacteria in presence of high organic matter, ammonia and/ or eutrophic conditions [20]. Due to the existence of oxygen-consuming materials in fresh water inflows much more than in seawater inflows, [4,12] DO is consumed in water of low salinity more than in that of high salinity. Moreover, during summer, considering the highly significant positive correlations found between BOD vs. PI and TIN; and ammonia vs. TIN whereas highly significant negative correlations found between DO vs. ammonia and TIN; and nitrate vs. EC, TDS, salinity and $\mathrm{Cl}$, it may be concluded that ammonia was the main $\mathrm{O}_{2}$ consumer via bio-oxidation to nitrate in lower salinity water.

The highly significant correlation between nitrite vs. TPAHs; $\mathrm{PO}_{4}$ vs. ammonia and TIN; and significant correlations between nitrite vs. $\mathrm{PO}_{4}$ during winter and between the parameters $\mathrm{PO}_{4}$ vs. ammonia during summer, indicated that these pollutants were from the same source which is Bahr El Baqur drain as discussed above.

Variation of some reported water quality parameters in Manzala Lake

Figure 9 shows comparisons of some important water quality features; $\mathrm{pH}$, salinity, DO, BOD, ammonia, nitrite, nitrate and $\mathrm{PO}_{4}$ values, of Manzala Lake and their linear fittings at different periods within the period 1920-2015. It can be concluded that $\mathrm{pH}$, salinity, $\mathrm{DO}$, nitrite and nitrate values are in a state of decreasing with different rates; whereas BOD, ammonia and $\mathrm{PO}_{4}$ are increasing. A good sign was the apparent decrease in nitrite concentration that reflects some improvement towards pollution treatment in Manzala Lake. However, the decrease in $\mathrm{pH}$, DO and salinity which was accompanied with a rising up of $\mathrm{BOD}$, ammonia and $\mathrm{PO}_{4}$ is apparently alarming us to keep efforts for improving the water quality of the lake. This is affecting directly the quality and diversity of fish as it was reported that marine catch species such as Mullet decreased constantly during the period 1920-1980 whereas fresh water species such as Tilapia increased [3,19] and the total fish catch of the lake was reported to decrease from 68 thousand tons in 2001 to a minimum value of 46.5 thousand tons in 2008 until it raised again [34]. Fortunately, the increase in ammonia concentration is accompanied by a decrease in $\mathrm{pH}$ that reduce its threat to aquatic life as illustrated in Table 5. The details of these studies are shown in Table 6.
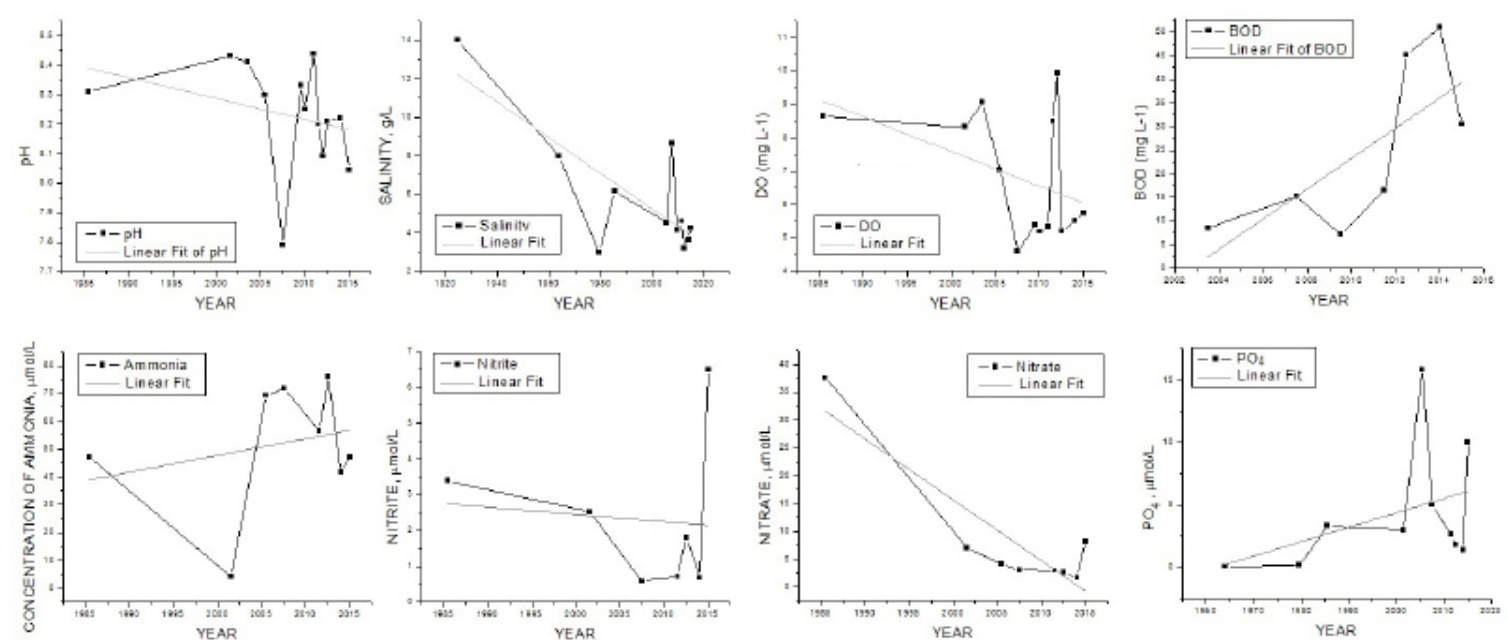

Fig. 9. Comparison of pH, salinity, DO, BOD, ammonia, nitrite, nitrate and PO4 concentrations of Manzala Lake during the period 1920-2015. 
TABLE 6. Comparison of some water quality parameter of Manzala Lake during the period 1920-2015.

\begin{tabular}{|c|c|c|c|c|c|c|c|c|c|c|c|c|c|c|c|c|}
\hline $\begin{array}{r}\text { Year } \\
\text { Parameter } \\
\end{array}$ & \begin{tabular}{|c|}
$1920-$ \\
1929
\end{tabular} & $\begin{array}{l}1962- \\
1966\end{array}$ & \begin{tabular}{|c|}
$1979 /$ \\
1980
\end{tabular} & $\begin{array}{l}1985 / \\
1986\end{array}$ & 2001/2002 & $2003 / 2004$ & 2005 & 2007/2008 & $\begin{array}{c}2009 / \\
2010\end{array}$ & 2010 & 2011 & $2011 / 2012$ & 2012 & $2012 / 2013$ & 2014 & 2015 \\
\hline $\mathrm{pH}$ & - & - & - & $8.31 *$ & $8.43^{*}$ & 8.41 & $8.30^{*}$ & 7.79 & 8.33 & $8.25 *$ & $8.44 *$ & 8.20 & $8.09 *$ & 8.21 & $8.22^{*}$ & 8.05 \\
\hline Salinity- $\left(\%_{0}\right)$ & 14.00 & 8.00 & 3.00 & $6.14 *$ & - & - & $4.52^{*}$ & 8.64 & 4.15 & - & - & 4.60 & - & 3.22 & $3.65^{*}$ & 4.26 \\
\hline $\begin{array}{l}\text { DO } \\
\left(\mathrm{mg} \mathrm{L} \mathrm{L}^{-1}\right) \\
\end{array}$ & - & - & - & $8.65 *$ & $8.32^{*}$ & 9.06 & $7.03^{*}$ & 4.59 & 5.38 & $5.19^{*}$ & $5.32 *$ & 8.50 & $9.95^{*}$ & 5.2 & $5.51^{*}$ & 5.74 \\
\hline $\begin{array}{l}\text { BOD } \\
\left(\mathrm{mg} \mathrm{L}^{-1}\right)\end{array}$ & - & - & - & - & - & 8.57 & - & 15.27 & 7.16 & - & - & 16.5 & - & 45.1 & $51.0^{*}$ & 30.5 \\
\hline Ammonia $\left(\mu \mathrm{mol} \mathrm{L}^{-1}\right)$ & - & - & - & $46.9^{*}$ & $* 4.15$ & - & $69.2^{*}$ & $71.8^{*}$ & - & - & - & $56.5^{*}$ & - & 75.9 & $41.8^{*}$ & 47.0 \\
\hline $\begin{array}{l}\text { Nitrite } \\
\left(\mu \mathrm{mol} \mathrm{L} \mathrm{L}^{-1}\right)\end{array}$ & - & - & - & $3.39^{*}$ & $2.52^{*}$ & - & - & $0.578^{*}$ & - & - & - & $0.71 *$ & - & 1.79 & $0.689^{*}$ & 6.49 \\
\hline $\begin{array}{l}\text { Nitrate } \\
\left(\mu \mathrm{mol} \mathrm{L}^{-1}\right)\end{array}$ & - & - & - & $37.6^{*}$ & $7.00^{*}$ & - & $4.07^{*}$ & $3.06^{*}$ & - & - & - & $2.90^{*}$ & - & 2.58 & $1.74 *$ & 8.18 \\
\hline $\begin{array}{l}\mathrm{PO}_{4} \\
\left.(\mu \mathrm{mol} \mathrm{L})^{-1}\right)\end{array}$ & - & $\begin{array}{c}0.063^{*}, \\
* * \\
\end{array}$ & $\begin{array}{c}0.172 *, \\
* * \\
\end{array}$ & $3.28^{*}$ & $2.98^{*}$ & - & - & $5.02 *$ & - & - & - & $2.61^{*}$ & - & 1.79 & $1.39^{*}$ & 9.99 \\
\hline Reference & {$[35]$} & [35] & [35] & {$[36]$} & [37] & [38] & [39] & [40] & [41] & [4] & [4] & [42] & [4] & [43] & [44] & $\begin{array}{c}\text { Present } \\
\text { work }\end{array}$ \\
\hline
\end{tabular}

$*=$ recalculated. $* *=$ total phosphate.

TABLE 7.Comparison of some water quality parameter of Manzala Lake with some principal drain effluents during the period 1998 - 2013

\begin{tabular}{|c|c|c|c|c|c|c|c|c|c|c|c|c|c|c|c|}
\hline $\begin{array}{r}\text { Year } \\
\text { Parameter }\end{array}$ & 1998/1999 & $\begin{array}{l}2001- \\
2010\end{array}$ & $\begin{array}{l}2001- \\
2010\end{array}$ & $2004-2006$ & 2006 & 2005-2008 & 2010 & 2011 & 2012 & 2013 & 2010 & 2011 & 2012 & 2013 & 2015 \\
\hline $\mathrm{pH}$ & 7.6 & 7.48 & 7.52 & - & - & $7.3-7.6$ & 7.30 & 7.49 & 7.72 & 7.69 & 7.73 & 7.65 & 7.92 & 7.86 & 8.05 \\
\hline $\mathrm{EC}(\mathrm{mmhoS} / \mathrm{g})$ & 1.78 & - & - & $0.41-6.92$ & - & - & 4.01 & 3.9 & 3.6 & 2.97 & 3.04 & 2.13 & 2.23 & 1.22 & 6.83 \\
\hline Salinity- $\left(\%_{0}\right)$ & 0.75 & - & - & - & - & - & - & - & - & - & - & - & - & - & 4.26 \\
\hline $\mathrm{DO}\left(\mathrm{mg} \mathrm{L}^{-1}\right)$ & 4.78 & 2.27 & 1.58 & - & 0.2 & $1.0-2.1$ & 1.18 & 1.42 & 1.62 & 1.98 & 1.62 & 2.34 & 1.80 & 1.70 & 5.74 \\
\hline $\mathrm{BOD}\left(\mathrm{mg} \mathrm{L}^{-1}\right)$ & 14.5 & - & - & $4.05-68.5$ & - & $28-100$ & - & - & - & - & - & - & - & - & 30.5 \\
\hline Ammonia $\left(\mu \mathrm{mol} \mathrm{L}^{-1}\right)$ & 47.2 & - & - & - & 821 & $100-250$ & - & - & - & - & - & - & - & - & 47.0 \\
\hline Nitrite $\left(\mu \mathrm{mol} \mathrm{L}^{-1}\right)$ & 2.17 & - & - & - & - & - & - & - & - & - & - & - & - & - & 6.49 \\
\hline Nitrate $\left(\mu \mathrm{mol} \mathrm{L}^{-1}\right)$ & 3.29 & - & - & $17.7-635$ & - & - & - & - & - & - & - & - & - & - & 8.18 \\
\hline $\mathrm{PO}_{4}(\mu \mathrm{mol} \mathrm{L}-1)$ & 7.22 & 0.92 & 0.79 & - & 80.1 & $8.25-23.7$ & - & - & - & - & - & - & - & - & 9.99 \\
\hline Source of water & $\mathrm{s}$ & $\mathrm{BB}$ & $\mathrm{H}$ & BB & BB & BB & BB & BB & BB & BB & $\mathrm{H}$ & $\mathrm{H}$ & $\mathrm{H}$ & $\mathrm{H}$ & $\mathrm{ML}$ \\
\hline Reference & [45] & {$[15]$} & {$[15]$} & [46] & [47] & [48] & [4] & {$[4]$} & [4] & {$[4]$} & [4] & [4] & [4] & {$[4]$} & $\begin{array}{c}\text { Present } \\
\text { work }\end{array}$ \\
\hline
\end{tabular}

.BB, $\mathrm{H}$ and $\mathrm{S}$ denote Bahr El Baqur, Hadus and El-Serw drains, respectively

Table 7 shows a comparison of some water quality parameter of Manzala Lake with principal drain effluents during the period 1998 - 2013. Bahr El Baqur drain clearly shows the worst water quality parameters which indicate that it has been the key problem and the key solution of most Manzala Lake issues. Also, this may explain why the south eastern region of the lake hosted the most deteriorated sites.

\section{Conclusion and recommendations}

Manzala Lake is suffering environmental changes where human activity such as construction of fish farms, roads and drying up large areas from the lake for agricultural purposes have changed the lake from a connected water body to semiclosed sub-basins, that are connected partially by narrow inlets. The northern portion of Manzala Lake differs much more than the southern portion along the whole year. The southern portion of the lake contains a relatively higher organic matter influenced by large waste effluents from different drains in particular Bahr El Baqur drain. On the other hand, the northern portion of the lake has a relatively higher salinity due to its nearness and impact of the Mediterranean Sea on it. The lake is highly eutrophic with nutrients and other toxic compounds such as petroleum hydrocarbons having access to people via the food chain beginning from algae and weeds to various kinds of fish and sea birds. It is highly recommended to continue efforts for effective treatment of waste effluents from different drains especially Bahr El Baqur drain. Also, the diffusion of seawater along the lake should be improved. Finally, it is advised to prohibit illegal land reclamation and intensive fishery especially with illegal methods to keep biological diversity of the lake.

\section{$\underline{\text { References }}$}

1. Ahmed, M. H., El Leithy, B. M., Thompson, J. R., Flower, R. J., Ramdani, M., Ayache, F. and Hassan, S., Applications of remote sensing to site characterization and environmental change analysis of North African coastal lagoons. Hydrobiologia, 622, 147-171 (2009). 
2. Rasmussen, E. K., Petersen, O. S., Thompson, J. R., Flower, R. J. and Ahmed, M. H., Hydrodynamicecological model analyses of the water quality of Lake Manzala (Nile Delta, Northern Egypt). Hydrobiologia 622, 195-220 (2009).

3. General Authority for Fishery Resources Development (GAFRD), Yearbook of Fishery Statistics in Egypt (2003-2012), Cairo, Egypt (2014).

4. Sallam, G. A. H. and Elsayed, E. A., Estimating the impact of air temperature and relative humidity change on the water quality of Lake Manzala, Egypt. J Na Resour Dev 5, 76 - 87 (2015).

5. Hereher, M. H., The Lake Manzala of Egypt: an ambiguous future. Environ Earth Sci 72, 18011809 (2014)

6. Khairy, H. M., Shaltout, K. H., El-Sheekh, M. M. and Eassa, D. I., Algal diversity of the mediterranean lakes in Egypt. Proceeding of the International Conference on Advances in Agricultural, Biological \& Environmental Sciences (AABES-2015) July 2223, London, UK (2015).

7. Environmental Protection Agency (EPA), Parameters of water quality, Interpretation and Standards, Wexford, Ireland (2001).

8. Vymazal J., Removal of nutrients in various types of constructed wetlands. Sci Total Env. 380, 48-65 (2007).

9. Barakat, A. O., Mostafa, A., Wade, T. L., Sweet, S. T. and El Sayed, N. B., Assessment of persistent organochlorine pollutants in sediments from Lake Manzala, Egypt. Mar Pollut Bull. 64, 1713-1720 (2012).

10. Azab, M. M., Darwish, A. A., Mahmoud, H. A., Sdeek, F. A., Residue levels of organochlorine pesticides in some ecosystem components of Lake Manzala. Environ Monit Assess 185, 10257-10268 (2013)

11. Kamel, E., Moussa, S., Abonorag, M. A. and Konuk, M., Occurrence and possible fate of organochlorine pesticide residues at Lake Manzala in Egypt as a model study. Environ Monit Assess . 187, 4161 (2015).

12. El Nemr, A., Said, T. O., Khaled, A., El-Sikaily, A. and Abd-Allah, A. M. A., The distribution and sources of polycyclic aromatic hydrocarbons in surface sediments along the Egyptian Mediterranean coast. Environ Monit Assess. 124, 343-359 (2007).

13. Sultana, R. and Rao, D. P., Bioaccumulation patterns of zinc, copper, lead, and cadmium in Grey Mullet, Mugil cephalus (L.), from harbour waters of Visakhapatnam, India. Bull Environ Contamin Toxic. 60, 949-955 (1998).
14. Bahnasawy, M., Khidr, A. A. and Dheina, N., Seasonal variations of heavy metals concentrations in mullet Mugil cephalus and Liza ramada (Mugilidae) from Lake Manzala. Egypt J Appl Sci Res. 5(7), 845-852 (2009).

15. Khadr, M. and Elshemy, M., Data-Driven Modeling For Water Quality Parameters Prediction Of The Drainage System Associated With Lake Manzala, Egypt, Eighteenth International Water Technology Conference, IWTC18, March 12-14, Sharm ElSheikh, Egypt ( 2015).

16. American Public Health Association (APHA), Standard method for examination of water and wastewater (20th ed). Washington: AWWA/ WPCE. American Water Works Association, Water Environment Federation. (1999).

17. Bailey N., Statistical Methods in Biology. Hodder and Stoughton, London (1981).

18. El-Asmar, H. M., Hereher, M. E., Change detection of the coastal zone east of the Nile Delta using remote sensing. Environ Earth Sci. 62(4), 769-777 (2015).

19. General Authority for Fishery Resources Development (GAFRD), Food and Fish, Cairo, Egypt, 32 (2015).

20. Chapman D., Water Quality Assessments - A Guide to Use of Biota, Sediments and Water in Environmental Monitoring - 2nd edn, United Nations Eucational, Scientific and Cultural Organization World Health Organization United Nations Environment Programme, E\&FN Spon, Chapman \& Hall, Cambridge, Great Britain (1996).

21. Abdo, M. H., Distribution of some chemical elements in the recent sediments of Damietta Branch, River Nile, Egypt. J Egypt Acad Soc Environ Dev. 5(2), 125-146 (2004).

22. Phocaides A., Water quality for irrigation. In: Technical handbook on pressurized irrigation techniques. Rome: FAO; Ch. 7. pp 79-97 (2000).

23. Thomann, R. V. and Muller, J. A. Principles of water quality modeling and control, Harper Collins Publishers, New York (1987).

24. Zeng, Y, Li and L. Zhao, H., The correlation analysis of COD and permanganate index in Jiuzhaigou water environment. Adv Mat Res. 933, 994-998 (2014).

25. United Nations Economic Commission for Europe (UNECE), Standard Statistical Classification of Surface Freshwater Quality for the Maintenance of Aquatic Life. In: Readings in International Environment Statistics, United Nations, New York and Geneva (1994).

Egypt. J. Chem. 60, No. 4 (2017) 
26. Donia, N. and Hussein, M., Eutriphication assessment of Lake Manzala using GIS techniques. Proceeding of the Eighth International Water Technology Conference, IWTC8, Alexandria, Egypt. 393 (2004).

27. Morales, J. A., Albornoz, A., Socorro, E. and Morillo, A., An estimation of the nitrogen and phosphorus loading by wet deposition over Lake Maracaibo, Venzuela. Wat Air Soil Poll. 128, 207221 (2001).

28. Chiaudini, G. and Vighi, M., The N/P Ratio and tests with Health \& Environment in Lakes. Water Res. 8, 1063-1069 (1974).

29. Forsberg, G. and Ryding, S. O., Eutrophication parameters and trophic state indices in 30 Swedish waste-receiving lake. Archiv Hydrob. 80, 189-207 (1980).

30. Smith, V. H. and Shapiro, J., Chlorophyll a-Phosphorus relations in individual lakes. Env Sci. Techn. 15, $444-451$ (1980).

31. Smith, V. H., Low N to P For Dominance by bluegreen algae in Lake, Phyt Sci. 225, 669-671 (1983).

32. Downing, J., McCauley, E., The nitrogen:phosphorus relationship in lakes, Limn Ocean, 37(5), 936-945 (1992).

33. Paytan A., Major Ions, Conservative Elements and Dissolved Gases in Seawater (lecture 4). In Marine Chemistry. Available at http://ocean.stanford.edu/ courses/bomc/chem/lecture_04.pdf (2006).

34. Samy-Kamal, M., Status of fisheries in Egypt: reflections on past trends and management challenges. Rev Fish Biol Fisheries, 25(4), 631649 (2015).

35. Toews, D. R., Fishery transformation on Lake Manzala, Egypt, during the period 1950 to 1980. pp. 25-50. In: N. W. Schmidtk (Ed.), Impact of toxic contaminants on fisheries management. CRC Press, Boca Raton. Florida (1988).

36. Khalil, M. T., The physical and chemical environment of Lake Manzala, Egypt. Hydrobiologia, 196, 193199 (1990).

37. Shakweer, L., Ecological and fisheries development of Lake El-Manzalah ((Egypt) 1. Hydrography and chemistry of Lake El Manzalah. Egy J Aqu Res. 31, 1110-0354 (2005).

38. Salah El Din R.A., Changes in physico-chemical characters and its impact on phytoplankton structure of Lake El Manzala. Egy J Phyc. 6, 111-126 (2005).

39. Elmoursi, R., Environmental impact assesment of pollution in lake El-Manzalla, Ph.D. Thesis, Tanta University, Egypt (2009).

Egypt. J. Chem. 60, No. 4 (2017)
40. Abdel-Rasheed, M. E., Ecological studies on lake El-Manzalah with special reference to their water quality and sediment productivity. PhD Thesis, AlAzhar University, Egypt (2011).

41. Egyptian Environmental Affairs Agency (EEAA), Ministry of Environment, Egypt. The annual report of periodical program of northern lakes monitoring. Available at http://www.eeaa.gov.eg/portals/0/ eeaaReports/water (2010).

42. Egyptian Environmental Affairs Agency (EEAA), Ministry of Environment, Egypt. The annual report of periodical program of northern lakes monitoring. Available at http://www.eeaa.gov.eg/portals/0/ eeaaReports/water (2012).

43. Egyptian Environmental Affairs Agency (EEAA), Ministry of Environment, Egypt. The annual report of periodical program of northern lakes monitoring. Available at http://www.eeaa.gov.eg/portals/0/ eeaaReports/water (2013).

44. Egyptian Environmental Affairs Agency (EEAA), Ministry of Environment, Egypt. The annual report of periodical program of northern lakes monitoring. http://www.eeaa.gov.eg/portals/0/eeaaReports/ (2014).

45. Shaaban - Dessouki,S. A., Deyab, M. A. and Mofeed, Jelan, Phycological Assessment Of Water Quality Of River Nile Delta - Egypt. Egyptian J. of Phycol. Vol. 5, 2004

46. El-Korashey, R., Using Regression Analysis to Estimate Water Quality Constituents in Bahr El Baqar Drain, J. App. Sci. Res., 5(8), 1067-1076, (2009).

47. Stahl, R., Ramadan, A. B., Pimpl, M., Bahr ElBaqar Drain System/ Egypt Environmental Studies on Water Quality Part I: Bilbeis Drain/ Bahr El-Baqar Drain, KR Forschungszentrum Karlsruhe in der Helmholtz-Gemeinschaft Wissenschaftliche Berichte, FZKA. Available at http://www.progreendiploma.com/wp-content/ uploads/2017/03/Nile-RIver-Water-QualityManagement-Study-1.pdf. (2009).

48. El-Sheikh, M. A., Saleh, H. I., El-Quosy, D. E. and Mahmoud, A, A., Improving water quality in polluated drains with free water surface constructed Wetlands. Ecolog Eng. 36, 1478-1484 (2010).

(Received:19/3/2017; accepted: 24/4/2017) 
الخصائص الفيزيوكيميائية لبحيرة المنزلة، مصر

راندا رمضان محمد المرسي ا ، محمد عبد الفتاح حامد ا و خالد صلاح أبو الثربيني

'قسم الكيمياء البحرية ـ المعهد القومي لعلوم البحار و المصايد و بقسم الكيمياء غير العضوية ـ المركز القومي

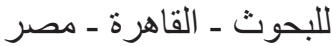

تم قياس المعاملات الفيزيائية و الكيميائية مثل درجة الحر ارة ومجموع المو اد الصلبة المذابة ودرجة الحموضئة و الملوحة

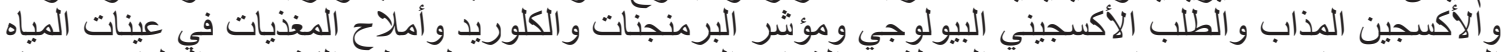

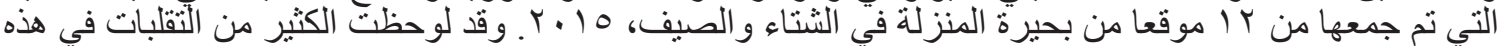

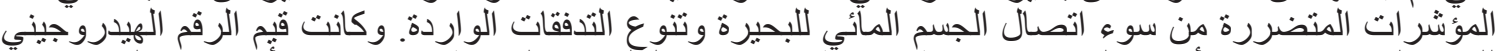

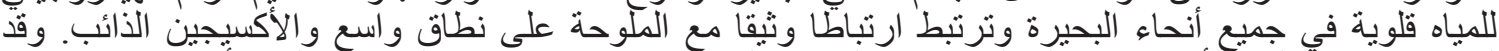

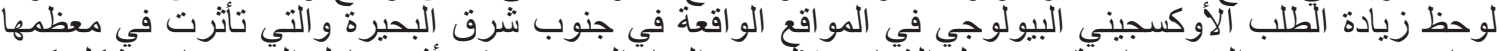

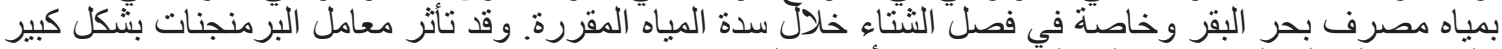

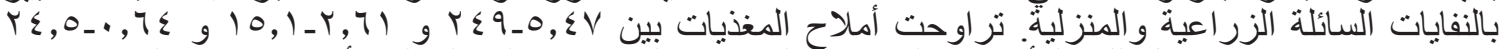

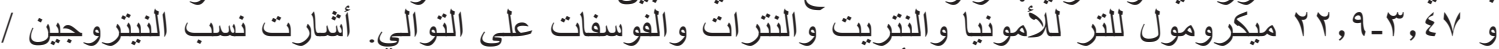

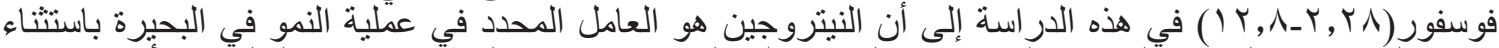

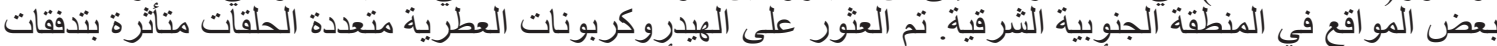

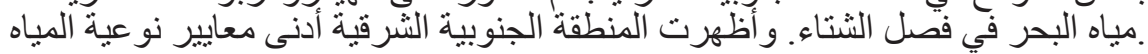

